\title{
Influence of Feeding Time on Sexual Maturity and Carcass Composition in Female Broiler Breeders
}

Author(s)

Avila VS de

Penz Jr. $\mathrm{AM}^{2}$

Rosa PS ${ }^{3}$

Brum PAR de ${ }^{4}$

Guidoni $\mathrm{AL}^{1}$

Ledur MC 6

Embrapa Suínos e Aves - Eng. Agr., DSc. vavila@cnpsa.embrapa.br

2 Universidade Federal do Rio Grande do Sul Eng. Agr., PhD. - ampenz@conex.com.br

3 Embrapa Suínos e Aves - Zootec., MSc. prosa@cnpsa.embrapa.br

${ }^{4}$ Embrapa Suínos e Aves - Méd. Vet., DSc. pbrum@cnpsa.embrapa.br

Embrapa Suínos e Aves - Eng. Agr., DSc. antilog@cnpsa.embrapa.br

Embrapa Suínos e Aves - Zootec., PhD. mledur@cnpsa.embrapa.br

\section{Mail Address}

Valdir Silveira de Avila

Embrapa Suínos e Aves

BR 153 km 110, Caixa Postal 21

Concórdia, SC

89.700-000

Fone: (0xx49) 442-8555

Fax: $\quad(0 x x 49) 442-8559$

E-mail:vavila@cnpsa.embrapa.br

\section{Keywords}

Broiler breeders, carcass composition, egg production, feeding time, sexual maturity.

\section{ABSTRACT}

One thousand two hundred and ninety six Arbor Acres females and 144 males were used to study the influence of feeding time on sexual maturity and carcass composition. Treatments were: $\mathrm{T} 1=$ feeding at $6: 30$ $\mathrm{am}, \mathrm{T} 2=50 \%$ feeding at $6: 30 \mathrm{am}$ and $50 \%$ at 3:30 pm (dual), T3= feeding at 11:00 am, T4 = feeding at 3:30 pm. Nutrition and management were as recommended to the commercial line. Variables studied were: sexual maturity at $5 \%$ production (SM), mean egg production percentage (PEP) body weight (BW), carcass composition, tibia weight (TIBW) and tibia calcium ( $\mathrm{Ca}$ ) and phosphorus (P) contents. Analysis of variance was used, and the means were compared using Student's t test. T2 females reached SM at 25.92 weeks, which was earlier $(p<0.01)$ than the other treatments. PEP was greater $(p<0.01)$ for $\mathrm{T} 1$ and $\mathrm{T} 2$ than for the other treatments. BW was greater in T1 and smaller in $\mathrm{T} 4(\mathrm{p}<0.05)$ than in the other treatments. TIBW was greater in T3 than in T1 and T2 $(p<0.05)$, with no effect ( $p>0.10)$ on carcass dry matter (DM), ether extract (EE), crude protein (CP) and ash (ASH). DM, EE, TIBW, Ca and $P$ increased $(p<0.05)$ whereas CP and ASH decreased with age. Time of feeding influenced body weight, but not carcass composition. Hens fed twice a day had earlier sexual maturity and similar egg production compared to those fed once at 6:30 am.

\section{INTRODUCTION}

The challenge to maintain body weight of female broiler breeders has been managed by the use of different diets or degree of feed restriction (Leeson, 1992). Robbins et al. (1988) and Katanbaf et al. (1989) reported that sexual maturity was anticipated and birds were heavier when female broiler breeders were fed ad libitum than when they were restricted. Robinson et al. (1995) also found that sexual maturity was earlier in female broiler breeders with adequate body weight than in birds with inadequate body weights.

According to Harms (1984), Leeson (1992) and Robinson et al. (1995), it is necessary to keep feed available for female broiler breeders so that they gain weight at an adequate rate. This approach allows a high peak and high persistence of egg production during the reproductive cycle. However, Robbins et al. (1988) observed that differences in diet composition and environment temperature can negatively affect egg production. Furthermore, Kohne et al. (1973), reported that feeding time is a factor that may lead to heat stress, due to the heat increment from exothermic reactions that happen during feed metabolism. Heat increment was higher $5 \mathrm{~h}$ after feeding in birds fed at 6:00 am than in birds fed at 2:00 pm when indoor temperature increased (Wilson et al. 1989). The usual procedure is to feed female broiler breeders once a day, in the morning. Cave (1981) and Bootwalla et al. (1983) questioned if the 
demand for nutrients is fulfilled in such a feeding scheme, especially during egg shell formation. To address this question, Cave (1981) evaluated different feeding schemes for female broiler breeders from 24 to 63 weeks of age, and reported no difference in egg production. The lowest weight gain, together with the heaviest egg mass, indicated that more frequent feeding allowed better partition of nutrients for egg formation instead of body tissue.

Considering the importance of obtaining more information on this subject, the objective of this study was to evaluate the effect of feeding time on productive performance, carcass composition, and tibia contents of calcium and phosphorus in female broiler breeders.

\section{MATERIAL AND METHODS}

This study was carried out at Embrapa - Swine and Poultry Research Center (Concórdia, SC, Brazi). At 20 weeks of age, 1,296 Arbor Acres female broiler breeders and 144 males from a different commercial line were housed in pens, with 27 females and 3 males per pen.

Birds were usually fed at 8:0 am. In order to change the feeding habits of the birds, the meal was distributed at 12:00 pm from 18 to 19 weeks of age. During the trial, the pelleted ration to be offered in the following day was mashed, weighed and loaded to the elevated feeders after the meal, in order to prevent stress. The amount of feed given to females was based on the number of hens per pen, body weight and egg production, whereas for males it was based only on body weight. The average body weight of males and females of four pens per treatment was evaluated at every two weeks.

During the trial, water was restricted to avoid moisture and was offered from 6:30 to 9:00 am, 11:00 am to $1: 30 \mathrm{pm}$ and from 3:30 to $6: 00 \mathrm{pm}$. Beak trimming and light program were according to Sadia's recommendations (Sadia, 1993).

The maximum and minimum temperatures were measured daily, starting at 31 weeks of age, using thermometers located in the middle of the facility.

A completely randomized experimental design was used, with 4 treatments and 12 replicates. Treatments were according to the feeding time: $T 1=100 \%$ of feed at $6: 30 \mathrm{am}, \mathrm{T} 2=50 \%$ at $6: 30 \mathrm{am}$ and $50 \%$ at $3: 30$ $\mathrm{pm}, \mathrm{T} 3=100 \%$ at $11: 00 \mathrm{am}$, and $\mathrm{T} 4=100 \%$ at $3: 30$ pm. Treatments began at 20 weeks of age and adaptation lasted until 24 weeks of age, when data collection began. Nutritional requirements were according to Sadia's recommendations for Arbor Acres stock. The composition of experimental diets(\%) in the pre-laying (from 18 to 23 weeks of age), production I (from 24 to 47 weeks of age) and production II (from 48 to 66 weeks of age) phases for female broiler breeders is presented in Table 1.

\footnotetext{
Table 1 - Ingredients, nutrients and energy content of diets fed to female broiler breeders during the pre-laying, production I and production || periods.
}

\begin{tabular}{|c|c|c|c|}
\hline Ingredients & $\begin{array}{l}\text { Pre - laying } \\
\text { (18-23 wk) }\end{array}$ & $\begin{array}{l}\text { Production I } \\
\text { (24-47 wk) }\end{array}$ & $\begin{array}{c}\text { Production II } \\
\text { (48-56 wk) }\end{array}$ \\
\hline \multicolumn{4}{|c|}{ Ingredients } \\
\hline Corn & 62.89 & 67.40 & 65.42 \\
\hline Soybean meal & 21.15 & 20.13 & 18.15 \\
\hline Wheat bran & 9.56 & 1.51 & 5.63 \\
\hline Limestone & 4.18 & 8.28 & 8.22 \\
\hline Dicalcium phosphate & 1.38 & 1.71 & 1.64 \\
\hline Salt & 0.33 & 0.41 & 0.42 \\
\hline Vitamin premix $^{1}$ & 0.20 & - & - \\
\hline Vitamin premix ${ }^{2}$ & - & 0.10 & 0.10 \\
\hline Mineral premix ${ }^{3}$ & 0.16 & 0.15 & 0.10 \\
\hline Methionine-DL & - & 0.20 & 0.15 \\
\hline Lysine-L & - & 0.02 & 0.01 \\
\hline Choline 60\% & - & 0.08 & 0.09 \\
\hline Anti-helmintic & - & - & 0.07 \\
\hline BHT & - & 0.01 & - \\
\hline TOTAL & 100.00 & 100.00 & 100.00 \\
\hline
\end{tabular}

\begin{tabular}{lccc}
\multicolumn{4}{c}{ Nutrients $(\%)$ and Energy } \\
Crude Protein & 16.50 & 15.00 & 14.50 \\
Metabolizable energy & 2,800 & 2,800 & 2,750 \\
Calcium & 1.70 & 3.10 & 3.20 \\
Available phosphorus & 0.37 & 0.40 & 0.40 \\
Total phosphorus & 0.64 & 0.61 & 0.63 \\
Methionine & 0.37 & 0.40 & 0.35 \\
Methionine + Cystine & 0.65 & 0.65 & 0.60 \\
Lysine & 0.80 & 0.75 & 0.70 \\
Tryptophan & 0.30 & 0.26 & 0.25 \\
Threonine & 0.62 & 0.57 & 0.55 \\
Arginine & 1.00 & 0.90 & 0.88 \\
Crude fiber & 2.95 & 2.60 & 2.67 \\
\hline T-Composition perkilogram: 10,000
\end{tabular}

1 - Composition per kilogram: 10,000 IU Vit. A; 2,500 IU Vit. D3; 30 IU Vit. $E_{i}$ 2.5 mg Vit. K3; 2.5 mg Vit.B1; 8 mg Vit. B2; 4 mg Vit. B6; 0.015 mg Vit B12; $45 \mathrm{mg}$ Nicotinic acid; $15 \mathrm{mg}$ Panthotenic acid; $1,400 \mathrm{mg}$ Choline; $0.20 \mathrm{mg}$ Biotin; $1.5 \mathrm{mg}$ Folic acid; $200 \mathrm{mg}$ B.H.T. 2 - Composition per kilogram: 12,000 IU Vit. A; 3,600 IU Vit. D3; 35 IU Vit. E; 3 mg Vit. K3; 2.5 mg Vit.B1; 8 mg Vit. B2; 5 mg Vit. B6; 0.020 mg Vit. B12; 40mg Nicotinic acid; $12 \mathrm{mg}$ Panthotenic acid; 0.20 mg Biotin; $1.5 \mathrm{mg}$ Folic acid. 3 - Composition per kilogram of diet: 70 mg Manganese; 75 mg Zinc; 40 mg Iron; 8 mg Copper; 0.5 mg lodine; $0.13 \mathrm{mg}$ Selenium; $600 \mathrm{mg}$ TM100; $250 \mathrm{mg}$ coccidiostatic.

The number of birds and the number of eggs from each pen were registered daily, from 25 to 66 weeks of age, and production per bird was obtained. The average percentage of total egg production/bird/day (PEP) and the sexual maturity at five percent of production (SM) were also evaluated.

Individual body weight (BW) for males and females was recorded for $100 \%$ of the birds at $22,28,40,46$, 
$52,56,60$ and 66 weeks of age, before feeding. Body weight was not evaluated between 28 and 40 weeks of age to avoid influences on the peak of production.

To evaluate carcass composition traits at the beginning of the trial (24 weeks of age), 12 birds not submitted to the treatments were slaughtered. Also, a sample of one bird/pen was taken at 40, 46, 56 and 66 weeks of age and killed by cervical dislocation to avoid blood loss. After plucking, the crop, esophagus, gizzard, pro-ventriculus and guts were removed, and contents were removed. The viscerae were frozen at $18^{\circ} \mathrm{C}$ with the carcass and other organs, until further carcass composition analysis was analysis.

For chemical analysis, frozen carcasses were cut in slices of approximately $5 \mathrm{~cm}$ wide, and samples were ground four times in an electric mill and mixed manually. Dry matter (DM), ether extract (EE), crude protein (CP) and ash $(\mathrm{ASH})$ were determined according to the method of the Association of Official Analytical Chemists (1984).

At $40,46,56$ and 66 weeks of age, one bird representing the average weight of the replicate was killed per pen. The right thigh was taken from each bird and dissected. Tibia weight (TIBW) was obtained, and $\mathrm{Ca}$ and $\mathrm{P}$ contents were determined using an atomic absorption spectrophotometer and the colorimetric method, respectively.

PEP, BW, DM, EE, CP and ASH were analyzed using the GLM procedure from SAS (1996), according to the following linear model:

$$
y_{i j k}=m+t_{i}+e_{i j}+s_{k}+t s_{i k}+e_{i j k}
$$

with $i=1,2,3,4$ treatments; $j=1, \ldots, 12$ pens; $k=1, \ldots$, $k$ weeks of evaluation, where: $y_{i j k}$ is the value of the response for the $i^{\text {th }} j^{\text {th }}$ pen at the $k^{\text {th }}$ week; $m$ is the overall mean from the experiment; $t$ is the effect of the $i^{\text {th }}$ treatment; $e_{i j}$ is the experimental error assuming a normal distribution with 0 mean and constant of variance $s^{2} ; s_{k}$ is the effect of the $k^{\text {th }}$ week; t $s_{i k}$ is the effect of interaction between the $i^{\text {th }}$ treatment and the $k^{\text {th }}$ week; $e_{i j k}$ is the week evaluation error assuming a normal distribution with 0 mean and constant of variance $s_{s}^{2}$.

The experimental error $\mathrm{e}_{\mathrm{ij}}$ was the term used to test the hypothesis on treatment effect and $e_{i j k}$ was the term used to test the hypothesis on the effect of week and interaction between treatment and week.

SM, TIBW, Ca and P were also analyzed with the GLM procedure of SAS (1996), using the following linear model:

$$
y_{i j}=m+t_{i}+e_{i j}
$$

with $i=1,2,3,4$ treatments; $j=1, \ldots, 12$ pens; where: $y_{i i}$ is the estimated value for the $i^{\text {th }} j^{\text {th }}$ pen; $m$ is the general mean; $t_{i}$ is the effect of the $i^{\text {th }}$ treatment; $e_{i j}$ is the experimental error, assuming a normal distribution with 0 mean and constant of variance $s^{2}$.

Treatment means for all evaluated variables were compared using Student's-t t test.

\section{RESULTS AND DISCUSSION}

The means for PEP and SM were different $(p<0.01)$ among periods of feeding (Table 2). Birds from T1 and $\mathrm{T} 2$ had the highest mean egg production (\%), while birds from T3, fed at 11:00 am, showed the lowest percentage. This difference can be attributed to heat stress, since during this period environmental temperature was high, combined with the heat increment from feeding in treatment 3. Egg production was significantly $(p<0.01)$ associated to the delay in sexual maturity, as shown in Table 2 . These results are similar to those reported by Harms (1991), who found lower egg production in birds fed late in the day. However, Cave (1981), Bootwalla et al. (1983), Brake (1988) and Samara et al. (1996) reported no differences on egg production when different feeding time schedules were compared.

Birds from T2 had earlier SM than birds from the other treatments (Table 2). Such birds probably showed better efficiency in utilizing the nutrients for egg production, and a possible maintenance of weight gain, resulting from the availability of feed twice a day. Birds from T4 presented significantly later sexual maturity than other treatments, although body weight at 28 weeks of age was similar to T2 (Table 3). Robbins et al. (1988) and Katanbaf et al. (1989) reported that sexual maturity was 14 and 60 days earlier, respectively, in birds fed ad libitum, when compared to restricted birds. Ad libitum feeding was favorable to body growth and to the consequent stimulus to anticipate egg formation. Robinson et al. (1995) reported a variation of $170 \mathrm{~g}$ in body weight, 5 to 9 days earlier sexual maturity, and an increase of 10 eggs between groups of light and heavy birds, indicating that body weight was not the only factor limiting the age at sexual maturity, but that feeding time had also a considerable influence.

Body weight means are presented in Table 3. The effects of treatment, week and the interaction between treatment and week affected body weight for both males and females (Figures 1 and 2). The interaction 
Table 2 - Sexual maturity at five percent of production (SM) and mean percentage of total egg production (PEP), from 25 to 66 weeks of age in female broiler breeders according to the feeding schedule.

\begin{tabular}{|c|c|c|c|c|}
\hline Variables & $\begin{array}{c}\mathrm{T}^{1} 1 \\
(6: 30 \mathrm{am})^{2}\end{array}$ & $\begin{array}{c}\text { T2 } \\
\text { (6:30 am 3:30 pm) }\end{array}$ & $\begin{array}{c}\text { T3 } \\
(11 \mathrm{am})\end{array}$ & $\begin{array}{c}\text { T4 } \\
\text { (3:30 pm) }\end{array}$ \\
\hline Sexual maturity (weeks) & $26.46 \pm 0.12 b^{3}$ & $25.92 \pm 0.12 c$ & $26.49 \pm 0.16 b$ & $26.89 \pm 0.14 a$ \\
\hline Egg production (mean \%) & $65.00 \pm 0.80 a$ & $65.20 \pm 0.80 a$ & $62.40 \pm 0.80 \mathrm{~b}$ & $64.40 \pm 0.80 \mathrm{ab}$ \\
\hline
\end{tabular}

Table 3 - Body weight $(\mathrm{g})$ of male and female broiler breeders, from 22 to 6 weeks according to feeding schedule.

\begin{tabular}{|c|c|c|c|c|c|}
\hline Weeks & \multicolumn{2}{|c|}{$\begin{array}{c}\mathrm{T}^{1}{ }^{1} \\
(6: 30 \mathrm{am})^{2}\end{array}$} & $\begin{array}{c}\mathrm{T} 2 \\
(6: 30 \text { am 3:30 pm) }\end{array}$ & $\begin{array}{c}\text { T3 } \\
\text { (11am) }\end{array}$ & $\begin{array}{c}\text { T4 } \\
\text { (3:30 pm) }\end{array}$ \\
\hline \multicolumn{6}{|c|}{ Males } \\
\hline $22^{3}$ & $3,180 \pm 53 a$ & $3,361 \pm 79 a$ & $3,298 \pm 76 a$ & $3,293 \pm 85 a$ & $3,283 \pm 37 E$ \\
\hline 28 & $4,070 \pm 58 c$ & $4,290 \pm 52 a b$ & $4,207 \pm 81 b c$ & $4,389 \pm 55 a$ & $4,239 \pm 35 \mathrm{D}$ \\
\hline 40 & $4,402 \pm 61 b$ & $4,573 \pm 81 a b$ & $4,750 \pm 98 \mathrm{a}$ & $4,759 \pm 75 a$ & $4,621 \pm 44 A$ \\
\hline 46 & $4,469 \pm 80$ b & $4,538 \pm 100 a b$ & $4,737 \pm 113 a b$ & $4,756 \pm 97 a$ & $4,625 \pm 51 \mathrm{~A}$ \\
\hline 52 & $4,444 \pm 91 a b$ & $4,309 \pm 67 b$ & $4,666 \pm 98 a$ & $4,666 \pm 83 a$ & $4,521 \pm 47 B C$ \\
\hline 56 & $4,368 \pm 104 a b$ & $4,274 \pm 149 b$ & $4,645 \pm 108 a$ & $4,546 \pm 98 a b$ & $4,458 \pm 60 \mathrm{C}$ \\
\hline 60 & $4,418 \pm 62$ b & $4,525 \pm 133 a b$ & $4,679 \pm 86 a$ & $4,736 \pm 55 a$ & $4,589 \pm 47 A B$ \\
\hline 66 & $4,426 \pm 75 b$ & $4,457 \pm 112 b$ & 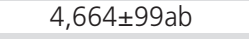 & $4,719 \pm 68 a$ & $4,566 \pm 48 A B$ \\
\hline MEAN & $4,222 \pm 49 b$ & $4,291 \pm 51 a b$ & $4,456 \pm 58 a$ & $4,483 \pm 55 a$ & \\
\hline \multicolumn{6}{|c|}{ Females } \\
\hline 22 & $2,254 \pm 8 a$ & $2,258 \pm 10 a$ & $2,251 \pm 10 a$ & $2,257 \pm 9 a$ & $2,255 \pm 5 \mathrm{H}$ \\
\hline 28 & $3,283 \pm 12 b$ & $3,338 \pm 6 a$ & $3,280 \pm 12 b$ & $3,344 \pm 11 a$ & $3,311 \pm 7$ G \\
\hline 40 & $3,956 \pm 11 \mathrm{c}$ & $4,030 \pm 13 b$ & $4,029 \pm 21 b$ & $4,103 \pm 14 a$ & $4,029 \pm 11 F$ \\
\hline 46 & $4,112 \pm 19 b$ & $4,131 \pm 14 a b$ & $4,150 \pm 17 a b$ & $4,176 \pm 16 a$ & $4,142 \pm 9 E$ \\
\hline 52 & $4,193 \pm 20 c$ & $4,206 \pm 14 b c$ & $4,254 \pm 20 a b$ & $4,299 \pm 17 a$ & $4,238 \pm 11 \mathrm{C}$ \\
\hline 56 & $4,165 \pm 18 b c$ & $4,142 \pm 27 c$ & $4,219 \pm 27 a b$ & $4,249 \pm 17 a$ & $4,194 \pm 13$ D \\
\hline 60 & $4,195 \pm 24 c$ & $4,255 \pm 14 b c$ & $4,303 \pm 28 a b$ & $4,321 \pm 20 a$ & $4,268 \pm 13 B$ \\
\hline 66 & $4,252 \pm 27 b$ & $4,350 \pm 20 a$ & $4,359 \pm 36 a$ & $4,367 \pm 19 a$ & $4,332 \pm 14 \mathrm{~A}$ \\
\hline MEAN & $3,801 \pm 67 c$ & $3,839 \pm 68 b c$ & $3,856 \pm 71 \mathrm{ab}$ & $3,890 \pm 71 a$ & \\
\hline
\end{tabular}

$1-\mathrm{T} 1=100 \%$ of feed at $6: 30 \mathrm{am}, \mathrm{T} 2=50 \%$ at $6: 30 \mathrm{am}$ and $50 \%$ at 3:30 pm, T3=100\% at 11:00 am, and T4=100\% at 3:30 pm. 2 - Means followed by different capital (small) letters in the column (row) are different $(p<0.05)$. 3 - In parentheses - time of feeding.

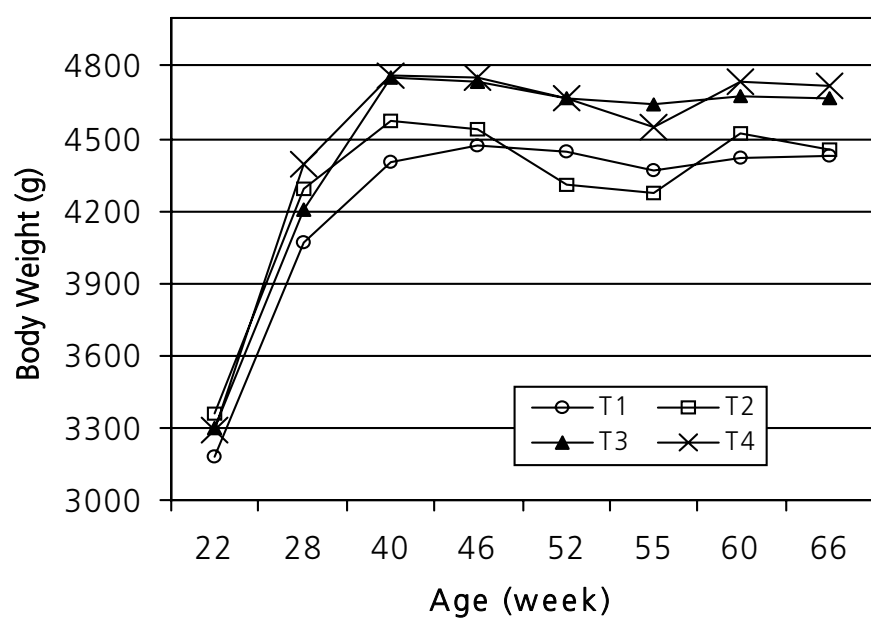

Figure 1 - Body weight of males broiler breeders according to age and feeding schedules $(\mathrm{T} 1=100 \%$ of feed at $6: 30 \mathrm{am}, \mathrm{T} 2=$ $50 \%$ at $6: 30 \mathrm{am}$ and $50 \%$ at $3: 30 \mathrm{pm}, \mathrm{T} 3=100 \%$ at $11: 00 \mathrm{am}$ and $\mathrm{T} 4=100 \%$ at $3: 30 \mathrm{pm})$.

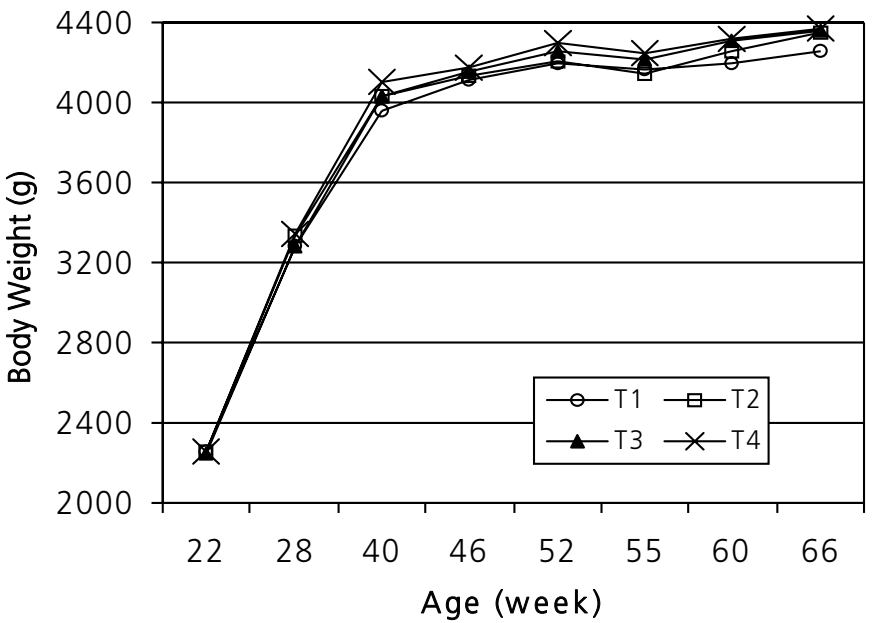

Figure 2 - Body weight of females broiler breeder according age and feeding schedules (T1=100\% of feed at $6: 30 \mathrm{am}, \mathrm{T} 2=$ $50 \%$ at $6: 30$ am and $50 \%$ at $3: 30 \mathrm{pm}, \mathrm{T} 3=100 \%$ at $11: 00 \mathrm{am}$, and $\mathrm{T} 4=100 \%$ at $3: 30 \mathrm{pm}$ ). 
showed that the difference between treatments started at 28 weeks of age. There was a drop in body weight around 56 weeks of age, possibly due to the low ambient temperature in some days during this production phase. Body weight had a normal growth curve, with fast growing in the beginning and decreased growth rate at 40 weeks or at the second production phase.

Broiler breeders from $\mathrm{T} 1$ and $\mathrm{T} 2$ had better body weight development, showing precocity and higher egg production than birds from the other treatments. This findings agrees with Harms (1984), who stated that female broiler breeders should gain more weight between 20 and 28 weeks of age, but gain should be slowed up to 36 weeks of age by restricting available food, allowing a high peak of egg production. Different levels of protein and different feeding time schedules were studied and it was reported that the lowest weight gain and the bigger egg mass were achieved with the most frequent feeding scheme, probably due to a better use of the nutrients for egg synthesis (Cave, 1981).

The high body weight for birds in T3 and T4 seems to be due to the influence of feeding time and to the great efficiency at feed utilization to produce fat instead of improving reproductive efficiency.

Maybe the stress caused by low ambient temperatures had affected males more than females, based on the amount of feed available for both sexes. Males showed feed intake and body weight very similar to the expected curve for the strain during the periods when environmental temperature was low. Despite the gradual reduction of feed, females were overweight if compared to the normal body weight of the strain, and showed reduced egg production, which was expected for that age. Females have more body stores to produce heat and overcome low ambient temperatures than males. This finding agrees with Samara et al. (1996), who fed female broiler breeders once or twice a day, at different temperatures, and observed significant reduction on body weight and feed intake, and besides, birds were more sensitive to temperature effects regarding feed intake.

Due to the high potential growth, males increased body weight with age, especially during the initial weeks (22 and 28). Weight gain was stable at the intermediate weeks (40 and 46), possibly due to the adjustment of maximum growth, and because of the management technique of replacing light or unproductive males. There was weight loss at the final weeks (52 and 56), possibly due to the stress caused by the low ambient temperature registered at 48, 53 and 59 weeks of age.
There was a compensatory weight gain at 60 and 66 weeks of age, when ambient temperature increased and a few number of copulations per day occurred, because a small number of females was kept in the pens during this phase. Similarly, it was reported that Ross males under feed restriction increased weight gain up to 54 weeks of age (Cerolini et al., 1995),. However, the group fed ad libitum decreased weight gain after 42 weeks due to heat stress. These findings support the idea that hens are sensitive to other factors than those related to body weight maintenance.

Mean minimum and maximum values for BW, DM, $\mathrm{CP}, \mathrm{EE}$ and $\mathrm{ASH}$ obtained from carcasses of female broiler breeders at 24 weeks of age are shown in Table 4. Weight was homogeneous, as evaluated by the standard deviation and the difference in weight between the minimum and maximum body weight and the mean. Thus, it is possible to say that the slaughtered birds are a representative sample of each group for such variables. The values of carcass composition were similar to those reported by Bennett \& Leeson (1990) for Hubbard female broiler breeders at 24 weeks of age and fed a diet containing $15 \%$ of protein and 3,080 $\mathrm{kcal} / \mathrm{kg}$ of ME. These authors for birds with mean body weight of $2,706 \mathrm{~g}$ reported the following levels: dry matter $-40.6 \%$; fat $-41.1 \%$; protein $-50.8 \%$ and ash $-8.4 \%$.

Bennett \& Leeson (1990) also reported a high correlation of protein and fat with body weight, which can be verified for all studied parameters shown in Table 4.

Table 4 - Body weight (g) and carcass composition (\%) $)^{1}$ for female broiler breeders at 24 weeks of age.

\begin{tabular}{lccccc} 
Variables & $\mathbf{N}^{\mathbf{2}}$ & Mean & Minimum & Maximum & STD $^{3}$ \\
Body weight & 11 & 2,676 & 2,624 & 2,727 & 37 \\
Dry matter & 11 & 33.39 & 30.79 & 35.36 & 1.64 \\
Crude protein & 11 & 45.40 & 38.38 & 50.34 & 3.41 \\
Ether extract & 11 & 35.97 & 30.74 & 44.43 & 4.03 \\
Ash & 11 & 9.54 & 7.87 & 10.83 & 0.88 \\
\hline $\begin{array}{l}\text { 1 - Values based on dry matter. 2 - N } \\
\text { Deviation. number of animals 3 - Standard }\end{array}$
\end{tabular}

Means for DM, CP, EE, ASH, TIBW, tibia Ca and P for each treatments and at 40,46, 54 and 66 weeks are presented in Tables 5 and 6 . There was interaction $(p<0.05)$ between treatment and week for $\mathrm{EE}$ and $\mathrm{Ca}$ in the tibia (Figures 3 and 4 ). Feeding time affected $(p>0.05)$ only TIBW. Treatment affected $(p<0.05)$ EE only at week 66 , where birds from $T 1$ had the lowest carcass fat content. However, due to the negative interaction, treatment effect could not be evidenced. 
Table 5 - Carcass composition of female broiler breeders slaughtered at 40, 46, 54 and 66 weeks of age according to feeding schedule ${ }^{1}$.

\begin{tabular}{|c|c|c|c|c|}
\hline Weeks & $\begin{array}{c}\mathrm{T1}^{2} \\
(6: 30 \mathrm{am})\end{array}$ & $\begin{array}{c}\text { T2 } \\
\text { (6:30 am 3:30 pm) }\end{array}$ & $\begin{array}{c}\text { T3 } \\
(11 \mathrm{am})\end{array}$ & $\begin{array}{c}\text { T4 } \\
\text { (3:30 pm) }\end{array}$ \\
\hline
\end{tabular}

\begin{tabular}{llllll} 
& \multicolumn{5}{c}{ Dry matter (\%) } \\
& & & & \\
40 & $40.3 \pm 0.7$ & $41.5 \pm 0.9$ & $41.1 \pm 0.5$ & $42.1 \pm 0.7$ & $41.3 \pm 0.4 \mathrm{C}$ \\
46 & $43.9 \pm 0.8$ & $43.5 \pm 0.9$ & $43.5 \pm 0.9$ & $42.6 \pm 0.4$ & $43.4 \pm 0.4 \mathrm{~B}$ \\
54 & $43.1 \pm 0.8$ & $43.6 \pm 0.6$ & $44.2 \pm 1.0$ & $45.8 \pm 1.6$ & $44.2 \pm 0.5 \mathrm{AB}$ \\
66 & $43.7 \pm 0.7$ & $46.6 \pm 0.4$ & $45.5 \pm 0.8$ & $44.8 \pm 0.5$ & $45.1 \pm 0.3 \mathrm{~A}$ \\
MEAN & $42.8 \pm 0.4$ & $43.8 \pm 0.4$ & $43.6 \pm 0.5$ & $43.8 \pm 0.5$ &
\end{tabular}

\begin{tabular}{|c|c|c|c|c|c|}
\hline \multicolumn{6}{|c|}{ Crude protein (\%) } \\
\hline 40 & $35.4 \pm 0.7$ & $36.0 \pm 0.8$ & $35.3 \pm 0.8$ & $34.8 \pm 0.8$ & $35.4 \pm 0.4 \mathrm{~A}$ \\
\hline 46 & $34.0 \pm 0.9$ & $34.7 \pm 1.0$ & $34.3 \pm 0.9$ & $35.2 \pm 0.7$ & $34.5 \pm 0.4 \mathrm{~A}$ \\
\hline 54 & $33.2 \pm 1.0$ & $32.5 \pm 0.5$ & $32.8 \pm 0.7$ & $32.8 \pm 0.7$ & $32.8 \pm 0.4 B$ \\
\hline 66 & $34.7 \pm 1.2$ & $30.4 \pm 0.6$ & $31.4 \pm 0.8$ & $32.4 \pm 0.6$ & $32.2 \pm 0.5 B$ \\
\hline MEAN & $34.3 \pm 0.5$ & $33.4 \pm 0.5$ & $33.4 \pm 0.5$ & $33.8 \pm 0.4$ & \\
\hline \multicolumn{6}{|c|}{ Ether extract (\%) } \\
\hline 40 & $51.4 \pm 0.9$ & $50.1 \pm 0.9$ & $49.7 \pm 1.4$ & $50.9 \pm 1.2$ & $50.5 \pm 0.5 B$ \\
\hline 46 & $52.2 \pm 1.2$ & $50.1 \pm 1.5$ & $51.9 \pm 1.3$ & $49.7 \pm 1.1$ & $51.0 \pm 0.7 \mathrm{~B}$ \\
\hline 54 & $53.3 \pm 1.3$ & $54.3 \pm 0.9$ & $56.6 \pm 1.2$ & $55.3 \pm 1.0$ & $54.9 \pm 0.6 \mathrm{~A}$ \\
\hline 66 & $50.0 \pm 1.8 b$ & $56.1 \pm 0.9 a$ & $54.9 \pm 1.0 \mathrm{a}$ & $52.9 \pm 1.0 \mathrm{ab}$ & $53.5 \pm 0.7 \mathrm{~A}$ \\
\hline MEAN & $51.7 \pm 0.7$ & $52.7 \pm 0.6$ & $53.3 \pm 0.7$ & $52.2 \pm 0.6$ & \\
\hline \multicolumn{6}{|c|}{ Ash (\%) } \\
\hline 40 & $7.4 \pm 0.2$ & $7.7 \pm 0.3$ & $7.8 \pm 0.2$ & $7.5 \pm 0.2$ & $7.6 \pm 0.1 \mathrm{~A}$ \\
\hline 46 & $7.1 \pm 0.2$ & $7.5 \pm 0.3$ & $7.6 \pm 0.2$ & $7.4 \pm 0.2$ & $7.4 \pm 0.1 \mathrm{AB}$ \\
\hline 54 & $7.6 \pm 0.2$ & $7.1 \pm 0.3$ & $7.0 \pm 0.2$ & $7.0 \pm 0.3$ & $7.2 \pm 0.1 \mathrm{~B}$ \\
\hline 66 & $7.7 \pm 0.3$ & $6.9 \pm 0.2$ & $7.1 \pm 0.1$ & $7.2 \pm 0.2$ & $7.2 \pm 0.1 \mathrm{~B}$ \\
\hline MEAN & $7.5 \pm 0.1$ & $7.3 \pm 0.1$ & $7.4 \pm 0.1$ & $7.3 \pm 0.1$ & \\
\hline
\end{tabular}

1 - Values based on dry matter. 2 - T1=100\% of feed at $6: 30 \mathrm{am}, \mathrm{T} 2=50 \%$ at $6: 30$ am and $50 \%$ at $3: 30 \mathrm{pm}, \mathrm{T} 3=100 \%$ at $11: 00$ am, and $\mathrm{T} 4=100 \%$ at $3: 30$ pm. 3 - Means followed by different capital (small) letters in the column (row) are different $(p<0.05) .4$ - In parentheses - time of feeding.

Table 6 - Mean values of traits related to the tibia of female broiler breeders slaughtered at 40,46, 54 and 66 weeks of age according to feeding schedule 1 .

$\begin{array}{ccccc}\text { Weeks } & \mathrm{T}^{2} & \mathrm{~T} & \mathrm{~T} & \mathrm{~T} \\ (6: 30 \mathrm{am}) & (6: 30 \mathrm{am} 3: 30 \mathrm{pm}) & (11 \mathrm{am}) & (3: 30 \mathrm{pm})\end{array}$

\begin{tabular}{|c|c|c|c|c|c|}
\hline \multicolumn{6}{|c|}{ Tibia weight (g) } \\
\hline 40 & $10.9 \pm 0.2$ & $10.9 \pm 0.3$ & $11.1 \pm 0.4$ & $10.8 \pm 0.3$ & $11.0 \pm 0.2 B^{4}$ \\
\hline 46 & $10.1 \pm 0.4$ & $10.0 \pm 0.3$ & $10.5 \pm 0.2$ & $10.6 \pm 0.3$ & $10.3 \pm 0.1 \mathrm{C}$ \\
\hline 54 & $11.9 \pm 0.4$ & $11.4 \pm 0.3$ & $12.8 \pm 0.5$ & $12.1 \pm 0.4$ & $12.0 \pm 0.2 \mathrm{~A}$ \\
\hline 66 & $11.0 \pm 0.3$ & $12.2 \pm 0.7$ & $12.5 \pm 0.6$ & $12.0 \pm 0.4$ & $11.9 \pm 0.3 \mathrm{~A}$ \\
\hline MEAN & $11.0 \pm 0.2 b$ & $11.1 \pm 0.2 b$ & $11.8 \pm 0.3 a$ & $11.4 \pm 0.2 \mathrm{ab}$ & \\
\hline \multicolumn{6}{|c|}{ Calcium (\%) } \\
\hline 40 & $23.2 \pm 0.2$ & $23.0 \pm 0.2$ & $22.9 \pm 0.2$ & $22.7 \pm 0,2$ & $23.0 \pm 0.1 \mathrm{C}$ \\
\hline 46 & $22.6 \pm 0.2$ & $22.5 \pm 0.2$ & $22.5 \pm 0.2$ & $22.7 \pm 0,2$ & $22.6 \pm 0.1 \mathrm{D}$ \\
\hline 54 & $23.2 \pm 0.2 \mathrm{ab}$ & $22.8 \pm 0.2 b$ & $23.5 \pm 0.2 a$ & $23.5 \pm 0.2 \mathrm{a}$ & $23.2 \pm 0.1 \mathrm{~B}$ \\
\hline 66 & $23.5 \pm 0.2$ & $23.8 \pm 0.3$ & $24.0 \pm 0.2$ & $23.7 \pm 0.2$ & $23.7 \pm 0.1 \mathrm{~A}$ \\
\hline MEAN & $23.1 \pm 0.1$ & $23.0 \pm 0.1$ & $23.2 \pm 0.1$ & $23.2 \pm 0.1$ & \\
\hline \multicolumn{6}{|c|}{ Phosphorus (\%) } \\
\hline 40 & $10.2 \pm 0.1$ & $10.2 \pm 0.1$ & $10.4 \pm 0.1$ & $10.2 \pm 0.1$ & $10.2 \pm 0.1 B C$ \\
\hline 46 & $10.2 \pm 0.1$ & $10.2 \pm 0.1$ & $10.2 \pm 0.1$ & $10.1 \pm 0.1$ & $10.2 \pm 0.1 \mathrm{C}$ \\
\hline 54 & $10.4 \pm 0.1$ & $10.2 \pm 0.1$ & $10.4 \pm 0.1$ & $10.3 \pm 0.1$ & $10.3 \pm 0.1 \mathrm{~B}$ \\
\hline 66 & $10.4 \pm 0.1$ & $10.4 \pm 0.1$ & $10.5 \pm 0.1$ & $10.5 \pm 0.1$ & $10.4 \pm 0.1 \mathrm{~A}$ \\
\hline MEAN & $10.3 \pm 0.1$ & $10.2 \pm 0.1$ & $10.4 \pm 0.1$ & $10.3 \pm 0.1$ & \\
\hline
\end{tabular}

1 - Based on DM and fat free. 2 - T1 $=100 \%$ of feed at $6: 30 \mathrm{am}, \mathrm{T} 2=50 \%$ at $6: 30 \mathrm{am}$ and $50 \%$ at $3: 30 \mathrm{pm}, \mathrm{T3}=100 \%$ at $11: 00$ am, and T4=100\% at 3:30 pm. 3 - In parentheses - time of feeding. 4 - Means followed by different capital (small) letters in the column (row) are different $(p<0.05)$. 


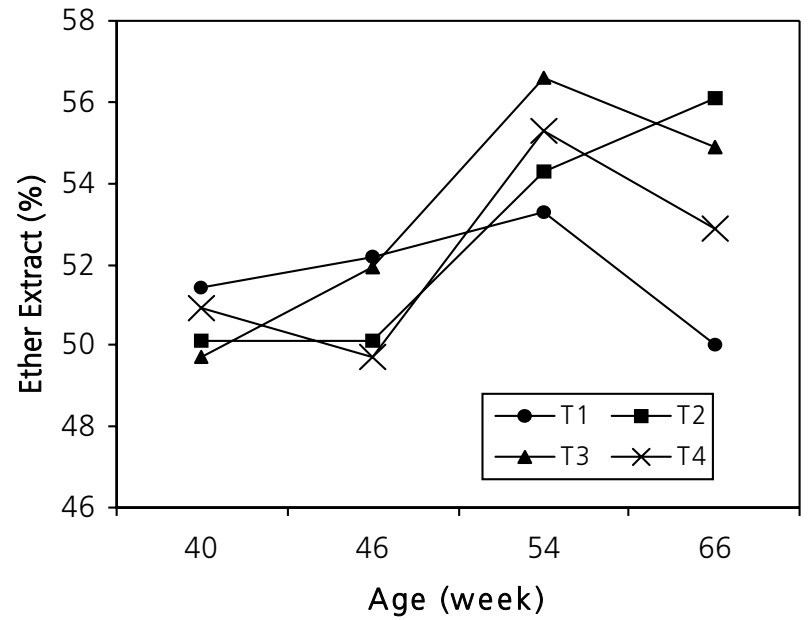

Figure 3 - Carcass ether extract in broiler breeders according to age and feeding schedules(T1=100\% of feed at $6: 30 \mathrm{am}$, $\mathrm{T} 2=50 \%$ at $6: 30 \mathrm{am}$ and $50 \%$ at $3: 30 \mathrm{pm}, \mathrm{T} 3=100 \%$ at $11: 00$ am, and $\mathrm{T} 4=100 \%$ at $3: 30 \mathrm{pm})$.

Week significantly affected $(p<0.05) D M, E E, C P$ and ASH. DM and EE increased with age, and were associated with BW, while CP and ASH decreased with age, indicating that the synthesis of protein in the tissues was stabilized, resulting in an increment of the adipose tissue, as shown in Table 5. These results agree with those of Robinson et al. (1995), that fed birds above and below of the recommended weight, and as a consequence, energy was deviated for carcass fat deposition instead of the reproductive process.

There was effect of treatment $(p<0.05)$ for TIBW, for birds fed at 11:00 am compared to those with other feeding schedule. The high TIBW can be related to the size of the bird, and proportionally associated to the low mobilization of $\mathrm{Ca}$ and $\mathrm{P}$ to the plasma required for eggshell synthesis. Bootwalla et al. (1989) fed female broiler breeders at different periods of the day and found that the plasma levels of $\mathrm{Ca}$ and $\mathrm{P}$ were influenced by feeding, stage of egg formation, and the moment of oviposition. No effect ( $p>0.05$ ) of treatment or interaction (treatment $x$ week) on $\mathrm{P}$ content in the tibia was observed. However, there was an interaction (treatment $x$ week) $(p<0.05)$ for Ca content, and birds from T1 and T2 showed similar Ca contents at week 54 , but lower than other treatments. Therefore, due to the negative interaction, the general effect of treatment was not evidenced. It can be speculated that this effect could be due to the prominent egg production around 54 weeks or to the great requirement of Ca mobilization for egg formation from both the tibia to the plasma and from the plasma to the calcium gland. Table 6 shows that

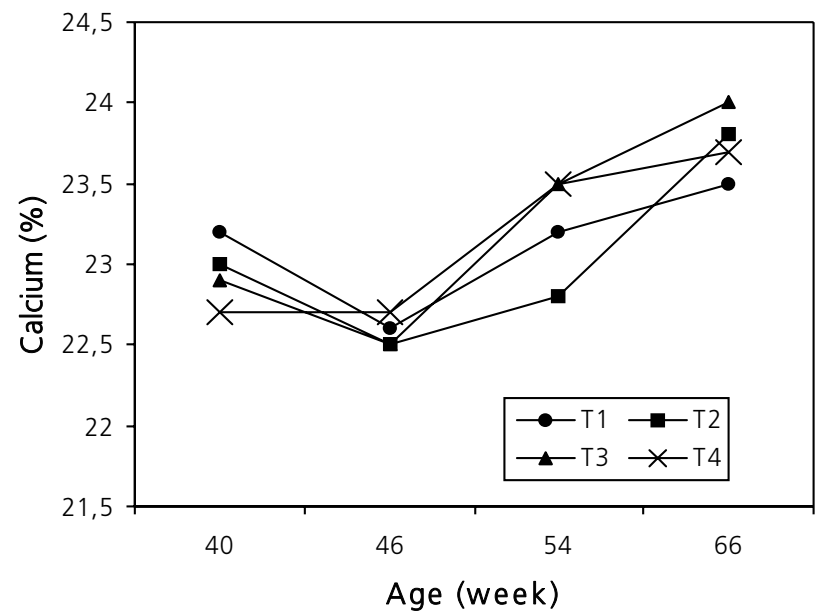

Figure 4 - Tibia Ca content in broiler breeders according to age and feeding schedules(T1 $=100 \%$ of feed at $6: 30 \mathrm{am}, \mathrm{T} 2=50 \%$ at $6: 30 \mathrm{am}$ and $50 \%$ at $3: 30 \mathrm{pm}, \mathrm{T3}=100 \%$ at $11: 00 \mathrm{am}$, and $\mathrm{T} 4=100 \%$ at $3: 30 \mathrm{pm}$ ).

the magnitude of the response increased $(p<0.05)$ with the age of the bird. This increase might have occurred due to the low mobilization of Ca and P from the bone used for eggshell synthesis, with the natural drop in egg production after the peak of production with advancing age (Table 6). Frost \& Roland (1990) suggested that the reduction of resistance and tibia weight with advancing age of female broiler breeders is due to the low reposition of $\mathrm{Ca}$. Thus, more experiments are necessary to find the correct hypothesis to these findings.

\section{CONCLUSIONS}

Feed given at 6:30 am or dual feeding determined the highest egg production and the lowest body weight; on the other hand, dual feeding induced earlier sexual maturity.

The different feeding time schedules had no influence on carcass composition.

\section{REFERENCES}

Association of Official Analytical Chemists (Arlington, USA). Official methods of analysis. 14.ed. Arlington.. 1984. 1141p.

Bennett CD, Leeson S. Education and production: Body composition of the broiler-breeder pullet. Poultry Science 1990; 69:715-720.

Bootwalla SM, Wilson HR, Harms RH. Performance of broiler breeders on different feeding systems. Poultry Science 1983; 62:2321-2325. 
Bootwalla SM, Wilson HR, Harms RH. Plasma calcium and phosphorus levels of broiler breeders with different feeding schedules. Poultry Science 1989; 39(2):391-398.

Brake J. Relationship of time and strain to egg shell quality and hatchability in broiler breeders. Poultry Science 1988; 67:538-543.

Cave NA. Effect of diurnal programs of nutrient intake on performance of broiler breeder hens. Poultry Science 1981; 60:1287-1292.

Cerolini S, Mantovani G, Bellagamba F, Mangiagalli MG, Cavalchini $L G$, Reniero R. Effect of restricted and as libitum feeding on semen production and fertility in broiler breeder males. British Poultry Science 1995; 36:677-682.

Frost TJ, Roland SR DA. The influence of vitamin $D_{3}, 1 a-$ hidroxyvitamin $D_{3}$ on eggshell quality, tibia strength, and various production parameters in commercial laying hens. Poultry Science 1990; 69:1008-2016.

Harms RH. The influence of feeding program on peak production and avoiding sudden declines in production with broiler breeder. Poultry Science 1984; 63:1667-1668.

Harms $\mathrm{RH}$. The influence of changing time of feeding on performance of broiler breeder hens. Poultry Science 1991; 70:1695-1698.

Katanbaf, MN, Dunnington EA, Siegel PB. Restricted feeding in early and late-feathering chickens. Reproductive Responses. Poultry Science 1989; 68:352-358.

Kohne HJ, Boone MA, Jones E. The effect of feed consumption on the survival time of adult turkey hens under conditions of acute thermal strees. Poultry Sicence 1973; 52:1780-1783.

Leeson S. Feeding programs for broiler breeder hens a major challenge. Better hen performance is achieved when body weight gain is optimum through the later transition period. Poultry Digest 1992; 51(2):24-41.

Robbins KR, Chin SF, Mcghee GC, Roberson KD. Effects of ad libitum versus restricted feeding on body composition and egg production of broiler breeders. Poultry Science 1988; 67:10011007.

Robinson FE, Robinson NA, Hardin RT. The effects of 20-week body weight and feed allocation during early lay on female broiler breeders. Journal of Applied Poultry Research 1995; 4:203-210.

Sadia, 1993. Agropastoril Catarinense Ltda. Manual Arbor Acres. Faxinal dos Guedes, SC. 26p

Samara $\mathrm{MH}$, Robbins $\mathrm{KR}$, Smith $\mathrm{MO}$. Interaction of feeding time and temperature and their relationship to performance of the broiler breeder hen. Poultry Science 1996; 75:34-41.

SAS Institute. Statistical analysis system. User Guide. SAS Institute Inc. Cary, NC. 1996
Wilson HR, Mather FB, Brigmon RL, Besch EL, Dugan VP, Boulus NZ. Feeding time and temperature interactions in broiler breeders. Poultry Science 1989; 68:608-616. 